\title{
POLA KOMUNIKASI DINAS PARIWISATA PEMERINTAH DAERAH KABUPATEN BANYUWANGI DALAM MENGEMBANGKAN POTENSI PARIWISATA MELALUI KEGIATAN FESTIVAL
}

\author{
. Hery Bambang. Cahyono \\ Prodi Ilmu Komunikasi Fakultas Ilmu Sosial dan Ilmu Politik \\ Universitas Muhammadiyah Jember \\ herybcahyono@gmail.com
}

\begin{abstract}
Banyuwangi was once just the easternmost district in East Java Province. This district is famous as an area that has the science of black magic, which is a very deadly black science. But now appear skyrocketed into a tourist area that is very amazing. Many tourism potentials are developed, there are also many tourist visits and ultimately can increase the dignity and economy of the community. This study wanted to find out the effective cooperation pattern of the Banyuwangi Regional Government Tourism Office in developing tourism potential through festival activities, the media used and the obstacles faced. The research method used is descriptive qualitative. The theory used is the theory of social exchange.

The results showed that the pattern of effective cooperation was carried out by the Department of Tourism by internally dividing tasks with all local government task units related to festival activities, while externally cooperating with all communities, especially cultural communities. Furthermore, the Tourism Office also promotes through internet media, print media, and interpersonal communication media. The results of this study also indicate that the obstacles faced the dilemma between the effort to develop tourism potential and the teachings of Islam, the low mastery of public information technology and the divided support between the people in the south and the people in the north towards cultural products as a tourism potential.
\end{abstract}

Keywords: Banyuwangi, Communication, Tourism

\begin{abstract}
Abstrak
Banyuwangi dahulu hanyalah sebuah kabupaten paling timur di Propinsi Jawa Timur. Kabupaten ini terkenal sebagai sebuah daerah yang mempunyai ilmu santet yaitu sebuah ilmu hitam yang sangat mematikan. Tetapi kini tampil melejit menjadi sebuah daerah wisata yang sangat mengagumkan. Banyak potensi wisata yang dikembangkan, banyak pula kunjungan wisata dan akhirnya bisa meningkatkan harkat martabat dan ekonomi masyarakat. Penelitian ini ingin mengetahui pola kerjasama efektif Dinas Pariwisata Pemerintah Daerah Banyuwangi dalam mengembangkan potensi pariwisata melalui kegiatan festival, media yang digunakan dan kendala yang dihadapi. Metode penelitian yang digunakan adalah deskriptif kualitatif. Sedang teori yang digunakan adalah teori pertukaran sosial.

Hasil penelitian menunjukkan bahwa, pola kerjasama efektif itu dilakukan oleh Dinas Pariwisata dengan jalan secara internal membagi tugas dengan semua satuan tugas pemerintah daerah yang terkait dengan kegiatan festival, sedangkan secara eksternal bekerjasama dengan semua masyarakat terutama masyarakat budaya. Selanjutnya Dinas Pariwisata juga mempromosikan lewat media internet, media cetak dan media komunikasi interpersonal. Hasil penelitian ini juga menunjukkan bahwa kendala yang
\end{abstract}


dihadapi adalah: adanya dilema antara usaha pengembangan potensi wisata dengan ajaran agama Islam, rendahnya penguasaan teknologi informasi masyarakat dan dukungan yang terbelah antara masyarakat di selatan dan masyarakat di utara terhadap produk budaya sebagai salah satu potensi pariwisata.

Kata Kunci : Banyuwangi, Komunikasi, Wisata

\section{Latar belakang}

Banyuwangi hanyalah sebuah kota kecil di ujung timur propinsi Jawa Timur. Tidak ada yang bisa dibanggakan seperti kabupaten lain yang ada di sekitarnya. Bahkan Banyuwangi identik dengan santet yaitu sebuah ilmu hitam yang dipergunakan untuk membunuh orang lain dengan cara yang halus. Pada era Presiden Abdurahman Wahid isu santet sangat banyak memakan korban dan juga menjadi salah satu yang meresahkan masyarakat. Melengkapi identitas santet di kawasan selatan tepatnya di Alas Purwo merupakan tempat yang ternama untuk mencari segala keperluan yang berbasis pada perdukunan dan klenik.

Tetapi kini Banyuwangi menjadi sebuah daerah yang sangat terkenal, tidak saja di dalam negeri tetapi hingga manca negara. Dahulu hanya menjadi kota transit menuju pulau Dewata Bali tetapi kini mampu menjadi salah satu destinasi tujuan wisata tersendiri. Bahkan tidaklah lengkap sebelum menuju Bali sebelum singgah di Banyuwangi. Kenyataan itu dapat dilihat dari sangat banyaknya wisatawan asing dan domestik yang menggunakan bandara Blimbingsari Banyuwangi. Lonjakan itu tidak saja dua digit tetapi dapat mencapai tiga digit. Kini Banyuwangi sangat "moncer" dalam percaturan arus pariwisata di Indonesia.

Salah satu faktor yang dapat meningkatkan jumlah pariwisata di Banyuwangi keberhasilan pemerintah daerah di bawah Bupati Azwar Anas untuk menggarap secara serius pariwisata di daerah tersebut. Tempat-tempat wisata yang dulunya hanya biasa-biasa saja dapat disulap dengan baik sehingga menarik wisatawan. Sebagai contoh adalah tempat wisata Pulau Merah yang dulunya hanya biasa saja tetapi dengan managemen khusus dan juga penyempurnaan sarana-prasarana dan menjadi sebuah destinasi wisata yang mengagumkan.

Pemerintah Kabupaten Banyuwangi di bawah Bupati Azwar Anas mampu untuk mewujudkan kerja sama yang baik antara pemerintah daerah dan masyarakatnya. Pemerintah daerah telah membuat berbagai macam festival sehingga setiap bulan selalu ada berbagai 
macam festival yang berbasis budaya, olah raga hingga festival keagamaan. Seperti festival Kuwung, Gandrung Sewu, Sego Cawok, Banyuwangi Argo Expo, Ijen Summer Jazz Java Banan, Wayang Kulit, batik dan masih banyak lagi, bila dijumlah tidak kurang dari 50 kegiatan. Semua kegiatan itu dinamakan "Banyuwangi Festival 2016". Kegiatan tersebut ternyata mampu meningkatkan peran serta masyarakat dalam membangun Kabupaten Banyuwangi.

\section{Rumusan Permasalahan}

1). Bagaimanakah pola kerjasama yang efektif Pemerintah Daerah Banyuwangi dengan masyarakat

dalam mengembangkan potensi pariwisata melalui kegiatan festival?

2). Media komunikasi apakah yang digunakan oleh Pemerintah Daerah Banyuwangi dalam bekerjasama dengan masyarakat untuk mengembangkan potensi pariwisata melalui kegiatan festival ?

3). Apakah hambatan-hambatan yang dihadapi oleh Pemerintah Daerah Banyuwangi dalam mengembangkan kerjasama yang efektif dengan masyarakat untuk mengembangkan potensi pariwisata melalui kegiatan festival ?

\section{Konsep Kerjasama Efektif Model Pertukaran Sosial}

Model ini memandang hubungan antar manusia (interpersonal) sebagai suatu transaksi dagang. Orang berhubungan dengan orang lain karena mengharapkan sesuatu untuk memenuhi kebutuhan . Thilbault dan Kelly dua pemuka dari model ini menyimpulkan bahwa model pertukaran sosial sebagai berikut:

"Asumsi dasar yang mendasari seluruh analisa kami adalah bahwa setiap individu secara sukarela memasuki dan tinggal dalam hubungan sosial hanya selama hubungan tersebut cukup memuaskan ditinjau dari segi ganjaran dan biaya." Ganjaran, biaya, laba dan tingkat perbandingan merupakan empat konsep pokok dalam teori ini (Rakhmat, Jalaluddin, $1998: 121$ ).

Ganjaran adalah setiap akibat yang dianggap menguntungkan yang diperoleh seseorang dari suatu hubungan. Ganjaran itu dapat berupa uang, penerimaan sosial, atau dukungan terhadap nilai yang dipegangnya.

Pertukaran sosial yang berbasis pada ganjaran berbeda dengan pertukaran yang berbasis ekonomi. Pertukaran ekonomi secara khusus meliputi kewajibankewajiban hukum, sedangkan pertukaran 
sosial bergantung pada kepercayaan dan kemauan baik (Budyatna, Muhammad, 2015:364). Pertukaran sosial bersifat sukarela tidak mengandung pemaksaan terhadap hak dan kewajiban. Pertukaran ekonomi memerlukan sebuah rincian yang eksak tentang imbalan-imbalan daan biaya-biaya dari kedua belah pihak, sedangkan pertukaran sosial membiarkan imbalan-imbalan dan biaya-biaya terbuka.

Jalaluddin Rakhmat melanjutkan bahwa nilai suatu ganjaran berbeda-beda antara seseorang dengan yang lain, dan nilai antara waktu yang satu dengan yang lain berbeda. Untuk orang kaya mungkin penerimaan sosial, penghargaan dan pengukuhan lebih berharga daripada ganjaran yang bersifat materi. Sebaliknya bagi orang miskin hubungan interpersonal yang dapat menyelesaikan kesulitan ekonomi lebih bernilai dari pada ganjaran yang bersifat penerimaan sosial dan pengetahuan. Urusan kebutuhan dasar menjadi penentu penilaian ganjaran.

Biaya adalah ongkos yang harus dibayar dalam suatu pertukaran sosial. Biaya itu dapat berupa waktu, usaha, konflik, kecemasan dan keruntuhan harga diri dan kondisi-kondisi lain yang dapat menghabiskan sumber kekayaan individu atau dapat menimbulkan efek-efek yang tidak menyenangkan. Seperti ganjaran, biayapun berubah-ubah sesuai dengan waktu dan orang yang terlibat didalamnya.

Kalkulasi ganjaran adalah hasil atau ganjaran dikurangi biaya. Jalaluddin Rakhmat melanjutkan bila seseorang merasa dalam suatu hubungan interpersonal tidak menghasilkan lama maka seseorang tersebut akan mencari hubungan lain. Bila berteman dengan orang yang pelit dan bodoh, maka hanya banyak membantu dan tidak mendapatkan keuntungan atau laba. Homan menyebut bahwa tidak ada pertukaran yang berlangsung jika kedua belah pihak tidak saling menguntungkan (Zeitlin, Irving M,1998 : 93). Hubungan seperti ini menurut teori pertukaran sosial tidak akan berlangsung lama kemudian retak bahkan putus. Akhirnya akan diganti oleh hubungan yang lebih menguntungkan.

Jalaludin Rakhmat melanjutkan bahwa tingkat perbandingan menunjukkan ukuran baku atau yang dipakai sebagai kriteria dalam menilai hubungan individu pada waktu sekarang yang banyak bergantung pada pengalaman masa lalu. Bila masa lalu telah mengalami hubungan interpersonal yang memuaskan maka akan menilai hubungan yang sekarang lebih rendah. Seorang gadis yang telah menjalin 
komunikasi interpersonal sangat baik pada masa lalu dengan teman kosnya, maka bila sekarang berhubungan dengan teman kos yang baru kurang memuaskan maka akan menilai hubungannya akan lebih rendah. Maka Muhammdyad Budyatna menyebut bahwa tingkat dimana hasil-hasil seseorang tergantung pada orang lain (Budyatna, Muhammad, 2015:364).

Teori pertukaran sosial sangat sesuai untuk membedah kerjasama yang efektif yang dilakukan oleh Pemerintah Daerah Banyuwangi dengan masyarakatnya. Karena pertama, Pemerintah Daerah Banyuwangi telah mendesain dengan baik semua kegiatannya dalam bentuk berbagai macam festival yang mampu mewadahi semua potensi yang ada di Banyuwangi. Selanjutnya terjadilah kerjasama yang efektif. Kedua, ternyata kerjasama itu keduanya saling mendapatkan ganjaran atau imbalan sebagaimana prinsip dasar teori pertukaran sosial. Masyarakat mendapatkan imbalan atau ganjaran dalam bentuk mental yang dapat berupa ekspresi diri, aktualisasi diri dalam berbagai macam festival, dan juga ganjaran dalam bentuk material yang ditandai dengan semakin meningkatnya kualitas hidup masyarakat.

\section{Metodologi Penelitian}

Penelitian ini menggunakan metode kualitatif, dengan menggunakan desain penelitian deskriptif analisis, yaitu penelitian yang diarahkan untuk mendeskripsikan atau menggambarkan pola komunikasi Dinas Pariwisata untuk mengembangkan potensi wisata. Adapun sasaran dalam penelitian ini adalah Dinas Pariwisata Pemerintah Daerah Kabupaten Banyuwangi Jawa Timur dam informan diambil dengan cara proposif. Adapun teknik pengumpulan data dalam penelitian ini adalah observasi, wawancara dan studi dokumentasi. Sedang analisa data menggunakan analisa deskriptif kualitatif.

\section{Hasil Penelitian}

\section{Gambaran Umum Lokasi Penelitian}

Banyuwangi adalah wilayah paling timur Pulau Jawa, berbatasan dengan Kabupaten Situbondo di utara, Selat Bali di timur, Samudra Hindia di selatan serta Kabupaten Jember dan Kabupaten Bondowoso di barat. Pelabuhan Ketapang menghubungkan Pulau Jawa dengan Pelabuhan Gilimanuk di Bali. Banyuwangi merupakan kabupaten terluas di Jawa Timur bahkan bisa dibilang terbesar di Pulau Jawa. Menurut informasi dari Potensi 
Pariwisata dan Produk Unggulan Jawa Timur, luas Kabupaten Banyuwangi mencapai 5.782,50 km2. Wilayahnya cukup beragam, dari dataran rendah hingga pegunungan. Kawasan ini berbatasan dengan Kabupaten Bondowoso, terdapat rangkaian Dataran Tinggi Ijen dengan puncaknya Gunung Raung (3.282 m) dan Gunung $\operatorname{Merapi}(2.800 \mathrm{~m})$ dengan terdapat Kawah Ijen.

Tidak berlebihan kalau dikatakan bahwa Kabupaten Banyuwangi adalah sebuah kabupaten yang paling majemuk di Propinsi Jawa Timur. Kawasan selatan seperti kecamatan Genteng, Gambiran, Pesanggaran, Bangurejo, Srono, Kalipait dan beberapa kecamatan yang lain dihuni oleh suku Jawa. Kebanyakan mereka berasal dari daerah Jawa Timur bagian barat dan sebagian besar dari Jawa Tengah.

Latar belakang daerah asal inilah yang menjadikan kabupaten Banyuwangi bagian selatan dalam keseharian memakai bahasa Jawa halus. Dialek bahasa Jawa Jogja dan Solo menjadi penanda yang tidak dapat dipisahkan. Dari aspek bahasa inilah yang membedakan dengan kabupaten Jember dan Situbondo yang berbahasa Madura. Kalau pun Jawa daerah kabupaten Jember dan Bondowoso bukan memakai dialek Jogja-Solo tetapi memakai bahasa Jawa dialek Surabanyan atau Jawa kasar. Atau dengan kata lain daerah Banyuwangi memakai bahasa Jawa mataraman, sedang daerah Jember dan Bondowoso memakai bahasa Jawa pesisiran atau tapal kuda. Bila tidak mengenal masyarakat Banyuwangi selatan maka akan mengira bahwa mereka bukan dari Banyuwangi tetapi dari Jawa Tengah.

Berbeda dengan daerah selatan, maka daerah utara seperti kecamatan Bajulmati dan Wongsorejo justru dihuni oleh mayoritas suku Madura. Selain menjadi nelayan atau melaut penduduk daerah ini sebagai petani dan juga pedagang. Selayaknya suku Madura pada umumnya juga memakai bahasa Madura dalam keseharian. Suku Madura sebenarnya juga berdiam di daerah perbatasan Banyuwangi dan Jember tetapatnya di kecamatan Kalibaru dan sebagian kecamatan Glemor. Mereka pun seperti suku Jawa di wilayah utara juga memakai bahasa Madura.

Bahasa Osing mempunyai banyak kesamaan dan memiliki kosakata Bahasa Jawa Kuno yang masih tertinggal. Namun di wilayah Banyuwangi sendiri terdapat variasi penggunaan dan kekunaan juga terlihat di situ. Varian yang dianggap 
Kunoan terdapat utamanya diwilayah Giri, Glagah dan "Licin, dimana bahasa Osing di sana masih dianggap murni. Sedangkan Bahasa Osing di Kabupaten Jember telah banyak terpengaruh bahasa Jawa dan Madura. Serta pelafalan yang berbeda dengan Bahasa Osing di Banyuwangi(https://id.wikipedia.org/wiki /Bahasa_Osing).

Kabupaten Banyuwangi mempunyai kesenian yang beragam sesuai dengan banyaknya budaya yang dimiliki. Berbagai macam budaya itu bisa berupa budaya yang berlatar belakang budaya Jawa, Madura, Bali hingga budaya Using itu sendiri. Akan tetapi seniman Banyuwangi mampu meramunya dengan baik sehingga sedikit berbeda dengan budaya yang lain. Potensi budaya inilah yang banyak dikembangkan oleh Dinas Pariwisata disamping potensi alam yang juga tidak kalah menarik.

\section{Pola kerja sama efektif Dinas Pariwisata Banyuwangi dalam mengembangkan potensi pariwisata melalui kegiatan festival}

Pola kerja sama efektif

Pola kerja sama efektif Dinas Pariwisata Banyuwangi dalam mengembangkan potensi pariwisata melalui kegiatan festival merupakan kerja sama yang efektif antara semua SKPD(Satuan Kerja Pemerintah Daerah) dan semua elemen masyarakat Kabupaten Banyuwangi. Pola kerjasama itu adalah sebagai berikut:

\section{Internal}

Asumsi awal peneliti bahwa Dinas Pariwisata menjadi tulang punggung tuggal dalam upaya meningkatkan jumlah kunjungan wisata atau dengan kata lain "menjual" Banyuwangi. Ternyata tidaklah demikian, Bupati Banyuwangi Azwar Anas telah menjalin komunikasi dan koordinasi yang sangat efektif antar dinas di lingkungan Pemda Banyuwangi. Kerjasama inilah salah satu kunci sukses upaya Dinas Pariwisata Banyuwangi untuk meningkatkan kunjungan wisata melalui berbagai macam festival.

Pola kerjasama internal yang efektif itu diawali dari identifikasi dari berbagai macam festival. Identifikasi itu sangat perlu karena setiap pelaksanaan selalu berubah atau tepatnya semakin bertambah. Pada tahun 2016 Banyuwangi Festival paling tidak menampilkan sekitar 52 kegiatan mulai dari kegiatan seni, olah raga hingga keagamaan dan sosial. Sedang pada tahun 2017 tercatat 72 kegiatan. Penambahan itu pada substansinya adalah sama, akan tetapi mengalami penyempurnaan. Seperti 
Festival Gandrung Sewu yang Pelajar, 4). Festival Patrol, 5). Barong pelaksanaannya beriringan dengan Banyuwangi Fashion Festival. Akan tetapi juga ada tambahan yang betul-betul baru seperti Festival Ngopi Sepuluh Ewu. Kegiatan itu tidak semata-mata merupakan dengan suatu festival akan tetapi merupakan menggali dari potensi masyarakat yang ada di desa adat Using.

Penentuan itu juga berkaitan dengan alokasi waktu pelaksanaan karena tidak mudah untuk mengatur lima puluhan kegiatan. Penentuan itu juga memperhatikan hari libur dan juga kebiasaan waktu kunjung turis asing. Yang jelas kerjasama internal itu selalu menampilkan waktu yang efektif untuk dilaksanakan dan dinikmati oleh semua masyarakat dan terlebih lagi bagi masyarakat wisata. Orang akan berkunjung ke Banyuwangi kini tinggal memilih waktu berkunjung serta kegiatan festival yang diminati, semua telah menjadi agenda tahunan mulai Januari hingga Desember.

Seperti dalam bulan Januari telah terpampang tiga kegiatan yaitu 1). Pentas Seni Budaya 2). Festival Jeding Ruig(Tolilet Bersih 3). Fastival Sedeka Oksigen. Bulan Juni ada tujuh kegiatan: 1). Banyuwangi Agro Expo, 2). Festival Durian Songgon, 3). Festival Hadrah Ider Bumi, 6). Sebang Olahsari. Demikian diujung tahun juga telah tertata rapi yaitu; 1). Festival EndhogEndhogan, 2) Festival Rowo Bayu, 3). Festival Gending Using, 4). Banyuwangi Painting \& Photography, 5). Festival Kuwung dan 6). Festival Kembang Api.

Penentuan festival itu juga berkaitan dengan tempat pelaksanaan. Seperti acara Tour De Banyuwangi-Ijen. Sebuah kegiatan yang melibatkan peserta dari banyak negara dan melintasi daerah yang amat luas mulai dari kawasan Gunung Ijen hingga beberapa kecamatan yang ada disekitarnya. Penentuan rute itu juga harus memperhatikan jarak, kondisi jalan dan lebih dari itu juga kondisi sosial. Artinya rute itu tidak saja hanya dilewati saja akan tetapi juga mempunyai nilai ekonomis untuk kemajuan UMKM. Perjalanan yang lama dan luas ini secara internal harus dipersiapkan dengan matang

Penentuan lokasi kegiatan festival juga berkaitan dengan pendukung kebudayaan. Karena Banyuwangi terbagai dua pendukung kebudayaan yang sangat besar di selatan merupakan pendukung kebudayaan Jawa, sebab kebanyakan berasal dari daerah Jawa Tengah dan juga Jawa Timur bagian barat 
selatan yang dalam konsep kebudayaan disebut dengan Mentaraman. Sedang di utara merupakan pendukung kebudayaan Using seperti di pusat kota, Kecamatan Glagah, Licin dan beberapa kecamatan yang lain seperti Kecamatan Rogojampi. Sedang di sebelah selatan seperti Kecamatan Genteng, Gambiran, Pesanggaran, Bangurejo hingga Srono merupakan kontong-kantong pendukung kebudayaan Jawa seperti wayang kulit, ketoprak, reog hingga jaranan.

Identifikasi dan penentuan itu juga menyertakan masyarakat secara luas. Artinya kerjasama internal itu juga membahas dengan matang dengan siapa harus bekerjasama. Jawaban itu bisa berkaitan dengan masyarakat senibudaya, masyarakat olah raga, pemuda hingga pihak keamanan. Menurut hasil penelitian kerjasama itu sangat serius dibahas dalam kerja sama internal. Seperti masalah keamanan dan lalu lintas hanya untuk satu kegiatan seperti kegiatan Internasional Tour de Banyuwangi - Ijen secara internal harus dipersiapkan kerjama dengan matang baik dengan pihak kepolisian, pemuda serta masyarakat yang lain.

Anggaran atau dana untuk semua kegiatan juga tidak lepas dari rapat koordinasi Bupati Banyuwangi. Di luar dugaan ternyata Pemda Banyuwangi tidak mengeluarkan dana yang sangat banyak, justru masyarakatlah yang tergerakan untuk mensukseskan setiap kegiatan sesuai dengan moto Banyuwangi "Jenggirat" yang artinya bangun, bergegas untuk berkarya. Pemerintah hanya mengeluarkan sedikit biaya seperti disampaikan oleh kasi kebuadayaan;" Kita rata-rata hanya menyumbang benner atau spanduk dan sejenisnya dan juga panggung atau terop." (Kepala Bidang Kebudayaan).

\section{Eksternal}

Pola kerjasama yang efektif Dinas Pariwisata Pemerintah Daerah Kabupaten Banyuwangi dalam mengembangkan potensi pariwisata melalui kegiatan festival sesungguhnya sangat sederhana tetapi sangat efektif. Hampir semua potensi daerah terlibat tidak saja masyarakat budaya tetapi juga masyarakat petani, olah raga, agama hingga masyarakat kuliner.

Pola kerjasama eksternal itu bisa digolongkan sebagai berikut:1. Masyarakat budaya yaitu masyarakat yang mempunyai keperdulian dengan kegiatan seni seperti janger, seblang, angklung dan kesenian yang lain. 2 . Kerjasama dengan pelaku seni atau penggiat kebudayaan inilah yang sungguh 
mengagumkan dan tidak dimiliki oleh masyarakat di beberapa kabupaten disekitarnya. Kasi Kebudayaan menyampaikan: "Banyak sekali pelaku seni yang sangat antusias untuk diajak kerja sama. Pelaku seni ini itu antara lain seni gandrung, seni batik, seblang, angklung dan masih banyak lagi". Di sinilah kelebihan pemerintah yang perduli dengan pelaku seni. Tidak cukup hanya di situ saja tetapi juga memperhatikan desainer dan juga pelaku seni yang lain.

(3) Menurut penuturan Kepala Bidang Pemasaran Dinas Pariwisata kerjasama dengan masyarakat media dengan jalan menggandeng anak-anak muda Banyuwangi untuk mengemas produk budaya untuk konsumsi masyarakat luas yang kemudian diunggah. Lalu peneliti bertanya dengan biaya berapa dengan ringan Kepala Bidang Pemasaran menjawab hanya memberikan sekedar uang untuk untuk biaya pulsa dan paket data. Bila berkaitan dengan media online seperti Kompas.com dan Detikcom pihak Dinas Pariwisata cukup memberi tahu adanya kegiatan fertival atau bahkan pihak media telah mengetahui dari kalender tahunan.

\section{Media yang digunakan}

Menurut hasil penelitian yang saya lakukan maka jenis media yang digunakan Dinas Pariwisata dalam dalam melakukan kerja sama efektif dalam mengembangkan potensi pariwisata melalui kegiatan festival adalah sebagai berikut(1)Media yang berbasis internet . Media yang berbasis internet adalah media yang paling banyak digunakan sebagai buktinya Dinas Pariwisata mempunyai banyak sekali video pendek yang mencerminkan kegiatan berbagai macam festival yang berbasis budaya, olah raga hingga keindahan alam pantai baik pegunungan hingga pantai. Seperti diungkapkan oleh Kasi Promosi Dinas Pariwisata:" Semua kegiatan festival selalu bekerjasama dengan anak-anak muda yang berkemampuan untuk urusan teknologi informasi. Merekalah sebenarnya menjadi tulang punggung dari promosisi wisata Banyuwangi." Promosi inilah yang sebenarnya sangat efektif untuk menjual Banyuwangi. Dan promosi model inilah yang dianggap sangat membantu masyarakat untuk meningkatkan kunjungan wisata. Hal ini diungkapkan oleh tokoh muda desa wisata di Kabupaten Banyuwangi yang juga sekertaris desa. Disampaikan Kasi Promosi;" Kita seringkali bekerjasama dengan media oneline seperti Detik.Com.,Kompas.com dan media yang lain". Kenyataan menunjukan hampir 
semua kegiatan festival selalu dimuat dalam media besar tersebut.

(2) Media cetak yang dimaksud adalah media harian cetak seperti Jawa Pos, benner, baliho, selebaran dan jenis media cetak lain. Seperti promosi pada umumnya banner dan baliho dipasang disudut-sudut jalan dan tempat yang penting. Bahkan hingga dipasang di luar kabupaten Banyuwangi seperti Jember yang berada disisi barat wilayah Banyuwangi.

Selebaran yang berisi kalender dan juga berbagai keunggulan kegiatan festival biasanya selalu dimiliki oleh semua SKPD dan menjadi alat promosi apabila datang ke berbagai daerah. Atau ketika ada tamu yang berkunjung yang kebanyakan adalah ingin meniru Banyuwangi yang dianggap telah berhasil meningkatkan kunjungan wisata daerah. Ketika peneliti mengadakan penelitihan telah datang satu bis dari Pemerintah Daerah Mojokerto. baliho serupa juga bisa dijumpai di pertigaan Perhutani.

(3) Media komunikasi interpersonal digunakan dengan jalan diterapkan oleh setiap SKPD. Kepala Dinas Sosial, Saiful Alam Sudrajat mengemas proposi Banyuwangi dengan cara sendiri yaitu menggunakan setiap peristiwa untuk mempromosikan Banyuwangi. Ketika ada kunjungan semua tamunya diajak ke Alas Purwo daerah pantai selatan yang terkenal dengan alam gaibnya, pantai Bangsring dengan keramba ikannya dan beberapa derah yang lain. Alam Sudrajat dengan bangga menampilkan keunggulan daerah yang sangat kaya dengan budayanya.

\section{Hambatan yang dihadapi}

Siapapun akan mengakui bahwa Kabupaten Banyuwangi sukses dalam mengembangkan potensi wisata daerahnya. Akan tetapi menghadapi banyak kendala yaitu:

\section{Perbedaan kepentingan}

Perbedaan kepentingan yang disebabkan keyakinan sangat dirasakan, akan tetapi tidak tampak mengemuka. Agama khususnya Islam menempatkan kebudayaan sebagai bagian dari agama termasuk sistem kepercayaan. Artinya semua produk manusia yang disebut dengan kebudayaan tidak boleh bertentangan dengan agama. Kreasi manusia dengan berbagai macam inovasi dan kreasinya harus merujuk pada ajaran agama. Fenomena ini juga muncul di Banyuwangi ketika mengembangkan kebudayaan lokal agar bisa dijual kepada masyarakat budaya. Kasi kebudayaan Dinas Pariwisata menyampaikan;" Ada penolakan dari kalangan agama ketika 
kami akan mengembangkan kebudayaan. Seperti festival Barong Ider Bumi pada awalnya juga mendapatkan pelokakan dari ulama setempat". Tetapi Kasi tersebut terus memberikan pemahaman bahwa hal seperti itu bukanlah ritual tetapi hanya sebatas kebudayaan. Selanjutnya Kasi tersebut menyampaikan bahwa pada akhirnya mereka bisa menarima seperti tuturanya;" Ya pada akhirnya mereka diam, tetapi mereka bisa menerima atau tidak, yang jelas sudah tidak ada gerakan untuk penolaan”.

Menurut pengamatan peneliti seperti di daerah lain di Jawa Timur umat Islam hampir pasti terbelah menjadi dua dalam menanggapi interaksi budaya dan agama Islam. Di satu sisi ada yang bersifat akomodatif dan sebagian justru sebaliknya. Banyuwangi yang mayoritas beretnis Jawa kebanyakan sangat akomodatif dengan masalah budaya dan agama sehingga hampir tidak ada masalah antara agama dan budaya. Sedang di sisi yang lain ada sebagian umat Islam yang kurang bisa menerima kalau budaya disandingkan dengan budaya. Kenyataan menunjukkan bahwa beberapa festival

Menurut hasil peneliti beberapa festival seperti kebo-keboan kurang bisa diterima oleh masyarakat Islam yang tidak bisa menerima bersandingnya budaya dan agama. Kecenderungan menunjukkan bahwa ketika budaya etnis Using dikembangkan banyak kembali pada budaya lama yang bersumber dari agama selain Islam. Dengan kata lain unsur-unsur kemusyrikan dalam konsep agama Islam yang dilarang secara keras justru dimunculkan. Termasuk didalamnya aspek mistik yang sering kali muncul dalam ritual-ritual budaya asli Banyuwangi yaitu budaya Using. Sekali Kasi kebudayaan Dinas Pariwisata selalu mengadakan pemahaman bahwa apa yang dilakukan hanya sebatas budaya.

\section{Keterbatasan teknologi informasi masyarakat}

Kendala penguasaan teknologi bersumber dari upaya Dinas Pariwisata yang menggunakan teknologi informasi untuk meningkatkan kunjungan pariwisata dengan mengunggah berbagai macam peristiwa budaya yang ada di masyarakat. Selain itu seperti daerah lain pada umumnya yang menggunakan teknologi informasi untuk memobilisir partisipasi masyarakat. Akan tetapi masyarakat yang mempunyai budaya kurang paham terhadap perkembangan teknologi komunikasi.

Pemerintah Daerah Banyuwangi tidak tinggal diam dalam melihat 
kenyataan seperti ini. Bahkan sejak beberapa tahun yang lalu diseluruh wilayah Kabupaten Banyuwangi yang mempunyai posisi strategis telah terpasang WIFI secara gratis. Seorang informan yang juga mahasiswa yang berasal dari Banyuwangi menyampaikan; "Saya pernah diminta untuk menjadi pendamping masyarakat dalam penggunaan teknologi informasi terutama dalam pengunaan HP Android, tetapi saya menolak karena harus kuliah" (Yuni,20 tahun). Itulah usaha pemerintah Banyuwangi dalam menjembatani kesenjangan penguasaan teknologi informasi untuk mendukung kunjungan wisata.

\section{Koordinasi masyarakat}

Upaya Dinas Pariwisata menjadikan budaya Using sebagai "dagangan" utama untuk menarik wisatawan tersebut sangat logis, akan tetapi kenyataan menunjukan bahwa pendukung budaya Using hanya ada dibeberapa kecamatan seperti Licin, Songgon, sebagian kecamatan Rogojampi dan wilayah kota Banyuwangi. Sedangkan disisi selatan yang sangat luas dan padat adalah pendukung utama budaya Jawa. Mereka berasal dari Jawa Tengan dan Jawa Timur yang biasa disebut dengan istilah daerah Mentaraman. Jadi belahan utara masyarakat Banyuwangi mendukung pengembangan budaya Using sedang masyarakat Banyuwangi selatan yang berbudaya Jawa tidak sepenuhnya mendukung.

\section{Kesimpulan}

Hasil penelitian ini menunjukkan bahwa pola kerjasama efektif yang dilakukan Dinas Pariwisata dalam mengambangkan potensi pariwisata sungguh sangat sederhana yaitu pemerintah mengadakan koordinasi dan pembinaan serta memberikan fasilitas yang sangat murah dan meriah tetapi hasilnya sangat menggembirakan. Kerjasama itu membuahkan hasil yang ditandai dengan meningkatnya jumlah wisatawan dan disusul dengan meningkatnya kesejahteraan masyarakat.

Pola kerjasama Dinas Pariwasata untuk mengembangkan potensi wisata melalui berbagai macam festival adalah dengan jalan bekerjasama dengan semua SKPD(Satuan Tugas Pemerintah Daerah) yang terkait. Bupati telah membuat kerja sama itu dengan baik dan Dinas Pariwisata sebagai ujung tombak. Seperti kegiatan festival yang berbasis budaya akan dilakukan oleh Dinas Pendidikan dan SKPD terkait demikian juga kegiatan festival yang berbasis olah raga, kuliner 
hingga keagamaan akan dilakukan oleh SKPD yang terkait.

Media yang digunakan untuk meningkatkan potensi pariwasata dengan melalui kegiatan festival adalah dengan melalui media yang berbasis internet seperti media oneline, media sosial dan bentuk yang lain. Selanjutnya juga menggunakan media cetak seperti selebaran, benner, baliho yang disebar sesuai dengan kepentingan dan yang tidak kalah pentingnya adalah dengan media komunikasi interpersonal.

Dinas Pariwisata sangat berhasil dalam mengembangkan potensi wisata di Kabupaten Banyuwangi, akan tetapi ada beberapa hal yang menjadi hambatan. Yaitu dilema yang seringkali bertentangan antara pengembangan potensi budaya dan ajaran Islam, kemampuan teknologi komunikasi masyarakat yang terbatas dan terbelahnya dukungan masyarakat yang ada di wilayah selatan dan wilayah utara. Keberhasilan Dinas Pariwisata yang sangat monumental adalah mampu membalas jerih payah masyarakat dengan meningkatnya kesejahteraan rakyat dan menaikan harga diri masyarakat Banyuwangi. Ganjaran itulah yang merupakan faktor penentu dari pola kerja sama tersebut.
Akhirnya, langkah yang telah dilakukan oleh Dinas Pariwisata dalam mengembangkan potensi pariwisata sungguh mengagumkan, akan tetapi akan semakin cepat berhasil apabila Dinas Pariwisata membimbing masyarakat untuk membangun jaringan komunikasi yang berbasis wisata. Jaringan itu mampu menghubungkan antara masyarakat pemilik wisata dengan biro-biro traveling yang semakin berkembang. Selanjutnya Dinas Pariwisata terus memperkuat kemampuan masyarakat dalam bidang teknologi komunikasi sehingga masyarakat dapat memasarkan produk wisatanya secara lebih mandiri.

\section{Daftar Pustaka}

Birowo, M. Antonius, Metode penelitian Komunikasi Teori dan Praktek, GITANYALI, Yogyakarta, 2004

Budyatna, Muhammad, Teori-Teori Komunikasi Antar-Pribadi, KENCANA, Jakarta, 2015

Effendy, Onong, U., Dinamika Komunikasi , Bandung: PT Remaja Rosdakarya, 2000

Herianti dan Winarno, Ilmu Sosial dan Budaya Dasar, BUMI AKSARA, Jakarta, 2012

Josep Eilers, Berkomunikasi Antar Budaya, NUSA INDAH, Ende, 1987. 
Kuntowijoyo, Budaya dan Masyarakat, Rakhmat, Jalaluddin, Psikologi TIARA WACANA YOGJA, Komunikasi, REMAJA ROSDA Yogyakarta, 1987.

KARYA, Bandung, 1998.

Koentjoroningrat, pengantar Ilmu Metode Penelitian

Antropologi, RINEKA CIPTA, Jakarta, 1990.

Moleong, Lexy, J., Metode Penelitian Naturalistik Kualitatif . Bandung : PT. Remaja Rosdakarya, 1992

Mulyana Deddy, Komunikasi Antarbudaya, Remaja Rosdakarya, Bandung, 1998

Komunikasi : Dilengkapi Dengan Analis Statistik, Bandung : PT Remaja Rosdakarya ,2000.

Sobur, Alex, Filsafat Komunikasi Tradisi dan Metode Fenomenologi, REMAJA ROSDAKARYA, Bandung, 2013.

Zeitlin, Irving M, Memahami Kembali Sosiologi, gajah Mada University Press, Yogyakarta, 1998.

Komunikasi, KENCANA, Jakarta, 2009

https://www.scribd.com/doc/227316696/

Nurhadi, Zikri Fachrul, Teori-Teori

Makalah-Pariwisata

Komunikasi (Teori Komunikasi

dalam Persektif Penelitian

Kualitatif)Ghalia Indonesia,Bogor, 2015 